\title{
THE SYMBOLISM OF HOARD DEPOSITION PLACES IN THE LANDSCAPE OF THE LATE BRONZE AGE AND THE EARLY IRON AGE IN THE ZONE OF THE SOUTH BALTIC COASTLAND AND LAKE DISTRICTS
}

\begin{abstract}
Maciejewski M. 2017. The symbolism of hoard deposition places in the landscape of the late Bronze Age and the early Iron Age in the zone of the South Baltic Coastland and Lake Districts. Sprawozdania Archeologiczne 69, $113-132$.

In different cultures the world is described by a variety of signs and symbols. Equally important as reading their meaning is an attempt to describe the relationships between them. Often seemingly unrelated elements of culture are linked by relations on a symbolic level. Research on the relationship between hoards (late Bronze Age and early Iron Age) and local settlement networks indicate such a symbolic connection between border and metal. Understanding these relationships is possible mainly thanks to empirical research yet it would not be possible without analysing the perception of borders and metal, as well as phenomena such as territoriality and the valorization of 'foreign' objects, places and people.
\end{abstract}

Keywords: hoards, cultural landscape, Bronze Age, early Iron Age, metal, border Received: 27.11.2016; Revised: 23.04.2017; Accepted: 26.05.2017

Hoard deposition places known from the late Bronze Age and the early Iron Age can be divided into different categories. Some of them were hidden within settlements or burial grounds, being ipso facto the elements determining the specificity of these places. Other were sunk in lakes, rivers, wetlands or swamps. The space occupied by bodies of water, watercourses and wetlands, as well as houses along with other places of daily activities and 
burial grounds constituted in each case only a part of inhabited microregions. Metal objects were also deposited within the other parts of oecumene as well as uninhabited zones. It gave individuals or groups freedom of choice of metal artefacts deposition places. Reflection on the cultural specifity of these communities, as well as space perception, leads to the conclusion that they have used the landscape to record cultural contents, amongst others, by depositing metal artefacts there. An attempt to read the said contents is possible thanks to analyses focusing on relationships between hoard deposition places and local settlement. Such studies combine very different categories of archaeological finds. On the one hand, there are spectacular, accurately dated, but discovered accidentally metal deposits. In such cases we often do not have information on the exact location and the direct context of discovery (Blajer 2001, 311-374). The second category consists of fragments of pottery discovered during surface prospection. In the case of period in question, the number of sites certified by such a prospection is very large. But we must remember that the methodology of such a research has its limitations, hence the location of human activity remains is not always possible (Mazurowski 1980, 13-34; Jaskanis 1996). Comparison of sources with such different features means that it is possible to carry out research only on a certain group of hoards, and specifically on 12 selected finds from the zone included to the South Baltic Coastland and Lake Districts according to J. Kondracki's (2009) regionalization.

The results of the aforementioned studies, as well as the principles of hoards selection for detailed analyses, were presented earlier in Sprawozdania Archeologiczne (Maciejewski 2015). This text is a continuation of that narration. It outlines the foundation of inference and a model proposed for interpretation of regularities recorded during the research on the relationships between the hoards deposition places and local settlement, also taking into account the specificity of natural and cultural landscape and, if possible, using information concerning the context of discovery of individual hoards.

Metal finds deposited en masse are difficult to interpet unambiguously. For decades of research on them a fairly limited set of premise was applied, used to support conflicting interpretations (Fontijn 2002, 13-21, table 2.1-2.3). Therefore, in the described research the scope of data was widened not only by the results of research on settlement networks, but also the spectrum of space reflection was taken into account. Interpretation of such a complex phenomenon requires consideration of a broad cultural context, meanings and functions (Stevens 2008, 246-247, fig. 2), which is presented below, showing first the symbolism of metal, then the cultural specificity of border perception, and finally to use these findings for the construction of an explanatory model.

\section{METAL}

The complex of meanings given to metal by communities of the Bronze Age and the early Iron Age, as well as the specificity associated with the production and acquisition of bronze (it can be assumed that copper, tin, gold, lead, and also iron in early stages of its use 
were similarly perceived - Maciejewski 2016, 40) is the basis for understanding the phenomenon of hoards deposition.

Bronze was both a raw material, a carrier of values, and a medium of acculturation. Its adoption was influenced not only by purely technological factors, archaeological sources indicate that it was a complex and non-linear process (Pare 2000, 24-25; Machnik 1982, 84-85). Introduction to the culture of a new raw material was not related to its technical advantage (Gediga 1982, 127), as indicated by an assortment of items made from metals during their dissemination, subtle way in which they were made and decorated (Bradley 1998, 82; Dąbrowski 2012, 88-89), as well as long cofunctioning of stone tools, and similarly classified metal objects (Dąbrowski 1992, 94; Dąbrowski 2012).

The adoption of bronze was associated with the necessity of the acquisition of alloy components, of which deposits available in prehistory were located in only a few zones of Europe. Hence, the possession of metal objects was associated with the need to obtain them or raw material required for metallurgical production by exchange (Pare 2000 24; Bartelheim 2009, 177-181 fig. 1; Brovender 2009; Fogel 1983, 142-143; Gedl 1982, 34, fig. 1; Makarowicz 2010, 365, fig. 6.19). The result of the limited availability of raw material was an intense exchange of both it and the ideas associated with it. Exchange networks, along with the subsequent stages of the Bronze Age became more local, but during the whole described period functioned centres, which along with the raw materials to disseminated cultural patterns (Pare 2000, 24, 29; Gedl 1982, 34). Participation in such a wide network of exchange resulted in the enrichment of the image of the world as a man of the Bronze Age and early Iron Age, apart from a sense of belonging to the local community, strengthened his awareness of being a member of the supralocal world (Fontijn 2002, 273274; Kristiansen and Larsson 2005, 39; Neustupný 1998, 15).

The relationship of metal with distant and unknown (for the majority of representatives of the Bronze Age communities) places meant that for these groups it gained an additional value (Suchowska 2010, 42). Understanding the specific valorization of 'foreign' elements in prehistoric cultures is possible, amongst others, due to the results of research on Indo-European languages. They suggest that a newcomer was identified with the supernatural powers or the dead. Indo-European peoples, such as the Hittites, the Greeks and the Indians, were convinced that supernatural beings spoke foreign languages. Examples of how meeting with 'strangers' looked in practice provides the history of great geographical discoveries and their anthropological analyses. Everything what was 'foreign' caused fear and yet fascination, adoration, affirmation and infatuation. The terms: 'stranger', guest or enemy formed a common semantic field, different from the contemporary one, presenting complex interpersonal relationships. The products of 'foreign' origins had supernatural powers, they could have had a positive impact on lives of people who came into contact with them. However, they can also bring misfortune. Such items were helpful for the materialization of ideas, however, they were much easier to control than meanings identified by them. Such a control gave a high social rank and could have even been the 
legitimacy of power. The value of an object was also connected with the valorization of place, from which the artefact or raw material came (DeMarrais et al., 1996, 17; Kowalski 1999, 16-20; Kristiansen and Larsson 2005, 39-41; Leeuw 1978, 79, 296; Mierzwiński 2012b, 553-554; Popko 1980, 37; Sahlins 2006; Załęska 2007, 38). The domestication of 'strangeness' - whether things or human - occurs by giving them a certain social role, without it their status was always low (Znaniecki 1999, 128, 137). In the case of metals, the acceptance of an exotic raw material could have been facilitated by its plasticity. 'Foreign' raw material was adapted to the local cultural system by melting, imitating local style or granting the symbolism expressed in ornamentation coincident with the local tradition (Bradley 1998, 82-83; Fontijn 2002, 254-255; Neustupný 1998, 25).

As already highlighted, the adaptation of a new raw material, so different from those previously known, was the result of a complex process. The ambiguous valorization of metal was also pointed out. The complex perception of bronze and products made of it is confirmed by the mythological communications. Because of the study period the most appropriate would be to refer to the Hittie mythology, and amongst these stories it is worth recalling the myth of the battle of gods. This story shows that a new order, which can be identified with the turn of the Stone Age and the Bronze Age arose by divine semen, compared to liquid bronze, to which the antidote, according to one of the old gods, was stone basalt (Popko 1980, 119-124). This example shows the ambiguous power of metal, on the one hand the destructive one, on the other hand enabling the construction of a new order. Melting may also often be equated with numerous rites connecting burning with a new beginning (Eliade 1993, 300). This ambiguity is also evident in the myths and rites referring to the motif of bronze cauldron, which was supposed to be deep underground or on the seabed and to hide sorrow, darkness, curse or illness. Amongst the Hittites were also known rites using such a cauldron to deposit impurity (sins), taking place where the customary funeral pyre was located (Popko 1980, 91-109). It is impossible here not to mention the importance of fire in the metallurgical process, which at the time of cremation burial rites played such a significant role in the ritual sphere (Kowalski 2006, 21; Mierzwiński 2012a). The mixing of such extreme meanings shows the complexity of metal perception within communities using it for short time. This perception was a blend of fascination with fear, it linked realities of the traditional cultural system with set to contact world of the Bronze Age.

\section{BORDER}

The functioning of humans in the world is based on gathering data about it, comparing, classifying, assessing and evaluating them. This is a multistep, complex and multifactorial process thanks to which an individual is able to find himself and act in the surrounding reality. This process, focused on the really existing, physical world, refers to a system of knowledge, values and norms of community to which the individual belongs. The cultural 
patterns in force influence the perception of the surrounding world by any person. At the same time, individual perception and the experience of reality of each community member impact upon these patterns by all forms of communication. Therefore, parallel and continuous processes of the individual and common development of the image of the surrounding world occur (Bartnicka 1985, 25-28, 32-33; Brown 2006, 233-247; Jałowiecki and Szczepański 2006, 333; Ogryzko-Wiewórkowski 2003, 171; Wallis 1990, 19, 26; Woźny 1999, 48; 2000, 37). The same rules are in force for granting meanings, describing and evaluation of physical space, as well as the adoption of these rules in social space and generally in culture. The results of research of representatives of various humanities and social sciences lead to the recognition that in the perception of the world, man separates some basic categories whose character varies in different cultural systems. However, certain properties are constant. Amongst the aforementioned categories of the description and organization of physical and cultural space, one of the most significant and widespread are borders.

Borders are delimited in space, as well as at the level of social relationships, when we use symbols to distinguish one class of things from the other. They constitute basic form of world organization. They do not have a material dimension, but characteristic elements of the landscape have it. The ambiguity of borders causes conflict and anxiety. They divide something in an artificial way which is continuous in nature, resulting in ambiguity being a cause of anxiety to both borders in time and space. Strengthening uncertain borders is to link them with social sanctions (Aristotle 2003, 85, verse 209b; Douglas 2007, 171; Leach 1989, 46-47; Tilley 1994, 17).

The border functions only when it is granted a meaning, even if it is materialized. Natural obstacles were indeed their prototype, but borders are formed regardless of the environmental conditions, both in places where there are various obstacles, as well as in those where they do not exist. On the other hand, borders are not delimited everywhere where natural conditions favour it (Tilley 1994, 17; Zapłata 2005, 27-28). Communities which live in similar natural conditions may perceive borders differently, as more or less absolute or rigid, depending on cultural norms, which are in force in them (Lévi-Strauss 1969, 129). The borders like relationships are dynamic, and sometimes even unstable. Rarely can one meet a very clearly drawn border, both in space, where usually it is a belt or zone, as well as in social life. However, their complete redefinition or cancellation is not an easy process. Borders are subject to a number of cultural sanctions (Anschuetz et al. 2001, 167; Czarnowski 1956, 227; Kantner 2008, 42; Tuan 1987, 194).

People living on both sides of physical borders, as well as social norms close to divisions marked out in culture, remain in a relationship. A borderland is a zone where such interactions take place. They can be based on: hostility indifference; rivalry manifested in presenting of own, variously understood, values; friendly combined with the acceptance of contacting; in unusual situations isolation. Borderlands are very dynamic and the relations which take place there generate new forms and cultural patterns. Their attributes are 
diversity, ambiguity and cosmopolitanism. Just as borders can be determined with different degrees of accuracy depending on the perspective from which we observe them (geopolitical borders, but also property borders), borderlands may also comprise different zones. Their range is partially associated with the scale in which we perceive them, and at the same time it depends on kind of relations taking place in such zones and media serving them. Therefore, a different borderland can be observed between two contemporary countries, and a different one between two prehistoric local groups. In the latter case, the borderland often can be identical to the border, understood as a belt or zone (Bujnicki 2006; Golka 1999, 14-18).

Crossing any border in space, time or society is often connected. It is always associated with a variety of more or less spectacular rites of passage (Buchowski 1987; Leach 1989, 48). Every crossing of them in space is related to special, designated places. These can be, for example: archways, doors, gates, doorsteps, bridges and fords. They protect certain places not only physically, but especially magically. Crossing them, particularly in traditional communities, should be seen as any other new situations, i.e. in a very ritualized manner. Granting the crossing places special power means that they become a protection against the mixing of the external and the internal world. They represent special locations which can be observed by their monumentality (e.g. portals of medieval cathedrals). Just as a border could have been crossed only in a certain place, it could only be done at a specific time (Buchowski 1987; Czarnowski 1956, 222; Douglas 2007, 149; Eliade 1974, 53; Jałowiecki and Szczepański 2006, 326-327; Leach 1989, 68-69; Popko 1980, 52).

The known world has always been divided by various borders, but easier to perceive and more important for the study of culture are the borders between the known world and the immense space beyond. The concept of the existence of such a space made it psychologically necessary for prehistoric man to put supernatural ideas or forces there. For representatives of traditional cultures these forces combining both demonic and divine characteristics filled just the reality outside of the oecumene. Therefore, it was mysterious and timeless, and the attempts were made to move there everything unclean or dangerous. 'Foreign' people and places located there were also seen in a specific way - equated with supernatural powers (Bystron 1939, 28-32; Czarnowski 1956, 223; Danka and Kowalski 2000, 240; Jałowiecki and Szczepański 2006, 326-327; Kowalski 1999, 16-20; Leeuw 1978, 179; Lejman 1999, 92; Mierzwiński 2012b, 553-554; Wojciechowski 1998, 146).

The division of the known world and the space outside is not a division which should be limited to simple oppositions such as nature - culture or good - evil. We should rather talk about the opposition of various metaphysical forces. Therefore, 'our' world, thanks to the separation of the unknown world - the dangerous one, gained a different specificity. Therefore, more important was the function of a border as addressed not to people, and especially members of the community marking it, but to these unknown forces. However, the space outside also could have been a temptation, a place where one be initiated or associated with supernatural forces (Czarnowski 1956, 222-223; Leeuw 1978, 88, 444). 
Therefore, border zones were places of ritual and rites which were aimed at its preservation as well as others being capable of corresponding with the supernatural. There were also special places, and perhaps social behaviour addressed to 'foreign' groups or individuals, even if they were not physically able to experience them (Tuan 1987, 194; Woźny 2000, 123, 143).

The creation of an image of the inhabited world is a part of identification processes, both individual and group, and thus occupying the same area as identity sources (Mamzer 2004, 130; Nowicka 1998, 381; Pellegriono 1989, 64; Posern-Zieliński 2000, 16; Wallis 1990, 19, 26; Wódz 1989, 258). Inextricably linked with the concept of identification is the phenomenon of territoriality. Clearly defined borders in a physical and social space are one of the tools for determining both the intimate zone and occupied area. Behaviour associated with territoriality according to E. T. Hall $(1987,64)$ varies and is intricately combined with other cultural elements (Hall 1978; 1984; 1987). He believes, too, that territoriality is a consequence of the territorial needs of man, going only beyond the place occupied by an individual and having to take into account the minimum distance between people. These needs are culturally conditioned, hence they are very diverse (Hall 1978, 144, 160-175). Different definitions of this phenomenon pay attention to its various aspects: division into spheres of influence, perception of certain areas as exclusive ones, need to defend a given space, appropriating a place or claiming rights to a given territory (Wódz 1989, 254). In the perspective of human groups, there is no simple addition of places occupied by individuals, because apart from personal territories, communities produce something which can be described as public territories (Wódz 1989, 255).

Territoriality is an inherent feature of human nature and with it is associated a discomfort which brings a sense of crowding and can result in stress, increased aggression, and consequently the collapse of cultural norms (Hall 1978). This sensation, like the minimum distance between people, is a cultural norm not related to population density, but to the discrepancy between the really available resources and the size of population (Woźny 2000, 94). Therefore, there are known traditional communities occupying vast areas, where the number of individuals is small, as well as those which live in small territories and the settlement density is very high. In order to avoid - in the latter case - potential aggression, very strict standards of cultural behaviour were introduced, including spatial ones discernible, amongst others, in behaviour related to border marking (Hall 1984, 181; Tuan 1987, 84).

The borders known from various levels of spatial organization and social life are a very complex tool of culture. From the perspective of an attempt to interpret the research in question, the most important are those delineated between oecumene and uninhabited zone. The symbolism of them was associated with the separation of known places from unknown space. In their perception, conflicting values blended. On the one hand, the need for security, on the other hand, the desire for adventure and visiting new places. 


\section{METALS DEPOSITED AT BORDERS - AN INTERPRETATION OF THE RELATIONSHIPS BETWEEN PLACES OF THE DEPOSITION OF METAL ARTEFACT HOARDS AND LOCAL SETTLEMENT}

This part of the narration requires a brief introduction of research results which are the basis of the presented model. A comparison of hoards, known from the study area and dated to the late Bronze Age and the early Iron Age, includes 432 finds. Archive research, information contained in the specialist literature and analyses of historical and contemporary maps made it possible to determine the exact or approximate location of 83 of them. All of these metal hoards were analysed, taking into account the characteristics of their inventory and topographical character of their deposition place (Maciejewski 2015, 6970). Detailed studies focused on a smaller group of finds, at the same time having the greatest research potential. These were hoards deposited outside settlements and burial grounds, they did not have a relationship with wet land. Taking into account the stage of research within the Polish Archaeological Record (Archeologiczne Zdjęcie Polski - AZP), availability of land for surface prospection and reliability of data from these studies allowed to designate a group of 12 hoards for further analyses. A systematic research on the settlement covered eight zones with a total area of over $5,000 \mathrm{~km}^{2}$. Four complementary and veryfying analyses were carried out taking into account 3,876 settlement points (Maciejewski 2015, 70-73). As a result of these studies it should be pointed out that the analysed hoards were deposited between inhabited zones or at borders between the oecumene and the uninhabited zone.

Such a wide range of research facilitated the availability of sources for settlement analyses, which of course had to be subject to multifaceted criticism from the constraints of the method, through the specifity of the programme the Polish Archaeological Record, to the specificity of particular zones and reliability of the results of prospecting carried out by different teams (Mazurowski 1980, 13-34; Jaskanis 1996). It is worth noting in this place that similar conclusions were made by other researchers based on a smaller range of data (Hołubowicz 1960, 96; Bradley 1998, 125-127, Figs. 27-28; Krajewski 2007, 39) and requiring discussion, for which there is no space here (broader Maciejewski 2016, 76-77). Also J.E. Levy (1982, 17-44) and A. Ballmer (2010) based on the religious study considerations and the results of anthropological research draw attention to the relation between hoard deposition places and borders.

Other characteristics of metal object deposition should also be pointed out and which will be referenced later in the argumentation. Some finds were deposited within stone and earthen structures. In the case of find from Rosko, site 47, Wieleń commune, Czarnków-Trzcianka district, based on excavations conducted there, and witness evidence, it can be pointed out that this structure was built to deposita hoard there (Machajewski and 
Maciejewski 2006). In the case of finds from Kaliszany, site 3, Wągrowiec commune, Wągrowiec district, the earthwork is still perceptible in the local landscape. The existence of such a structure in Stołężyn, Wapno commune, Wągrowiec district is indicated by archive records. For these two finds at the current stage of research there is also likely an interpretation indicating that the earthworks were structures similar to the one known from Rosko, although they could also have been earlier barrows (Maciejewski 2016, 112-115, 145-146, 170). Similar records also apply to several other finds from Pomerania and Greater Poland and their verification requires further research (broader Maciejewski 2016, 146). It should be kept in mind that, despite the limited knowledge about the discovery circumstances, a relationship with stones and some of the hoards may be indicated (Blajer 2001, 256, fig. 42). Amongst the analysed group an example can be Granówko, Granowo commune, Grodzisk Wielkopolski district. This repeatability may suggest a symbolic significance of individual stones or stone structures.

Another important observation is the relationship of some hoards with potential microregion scale routes. It results, as in the case of Rosko, from the specificity of local settlement and location near watercourses relevant to local contacts (Maciejewski 2006, 212213, fig. 6). On the other hand, in Kaliszany such a nature of the hoard is indicated by the terrain relief - the hoard was deposited on a promontory slightly elevated above the surrounding wetlands (Maciejewski 2016, map 24). In the case of Bobrowiczki/Sławno, site 4, Stawno commune, Stawno district, the historical record shows the location here of both a north-south route along the Wieprza River, as well as an east-west route at a convenient crossing of the aforementioned river (Spros 1994, 37-39).

Also very interesting is the deposition place of the hoard from Żelazo, site 50, Smołdzino commune, Stupsk district. It was discovered on a moraine hill called Białogóra, which is located within the Rowokół Natural Reserve covering a massif of post-glacial elevations cut by the Łupawa River valley. At the point where the assemblage of metal objects in question was discovered, the terrain rises to a height of about $40 \mathrm{~m}$ above sea level, which means that the denivelation in regard to the surrounding valleys is approximately $20 \mathrm{~m}$. However, the culmination of this terrain form (Rowokóf) located to the west, across the river, rises higher, i.e. to $114.8 \mathrm{~m}$ above sea level. The hill is clearly visible from both local lakes and sea (and therefore it constituted an indicative point for sailors), as well as from land. Excavations conducted there revealed the remains of Early Medieval and Post-medieval settlement, their results also point to the religious symbolism of this place. The hill in the folk tradition was also a place associated with numerous myths and legends. It can be assumed that in the analysed period such a characteristic terrain form had a number of symbolic meanings for the analysed communities, and that supernatural forces could have been located there (broader Maciejewski 2016, 105-106, there further references).

Another finding worth mentioning is a lack of connection between the topographical specificity of hoard deposition places and a selection of items that were part of their inventory (Maciejewski 2015, 70). 
The key to understanding the symbolism of acts of metal deposition in marginal areas of inhabited areas is the similarity in the perception of the two previously characterized categories: metal and border, as well as the specifity of understanding of 'foreign' places, objects and people and increasing in the late Bronze Age sense of territoriality.

Metal fascinated and yet terrified. Since it was something new, unusual and exotic, it had the importance of prestige and created the possibility of producing items previously unavailable. Also convergent was the symbolism of borders separating the two categories corresponding to the duality of human nature. On the one hand, the need for stability and security, and on the other hand the thirst for adventure arousing both fear and curiosity, being a threat, but also giving the opportunity to gain prestige, knowledge, contact with supernatural powers and ancestors, to acquire exotic items or raw materials, and consequently even power. This symbolic similarity allows us to understand why communities of the late Bronze Age and the early Iron Age in the analysed area deposited metal objects at the borders of inhabited zones. A fuller understanding of the importance of these activities is possible thanks to study of the different spheres of life of groups in question and the specificity of some finds.

The described location of hoards was also associated with their practical function. Such places organized the physical world and helped participants to act within it. They were both markers of borders and passages as well as characteristic points on local and perhaps supra-regional routes. The term hoard map gains ipso facto a new meaning, binding these finds within a narrativized space. Some of the studied finds were deposited in places which for various reasons facilitated displacement (Kośko and Kločko 2011). The lack of such observations concerning other analysed hoards does not rule out that they were connected with similar routes. Unfortunately, archaeological sources, which may indicate directly the existence of such local connections are discovered very rarely (Rączkowski 2011).

The existence of the aforementioned monumental stone structures built in places of metal object deposition, on the one hand confirms the quoted interpretation concerning metal object deposition places as important points in the landscape, and on the other hand it draws attention to the nature of the metal deposition act. If it was associated with the construction of the aforementioned structures, it was a previously prepared action carried out by a larger group. Hence the purpose of metal object deposition was not to hide them because of their material value or storage, as is often suggested in the interpretations of such finds. An important element of these structures were stones, which is also recorded in other cases. Recalling the Hittite myth of the battle of gods and symbolic meaning of metal presented earlier - a symbol of a new era - and stone - which could mitigate the power of liquid bronze - an attempt at interpretation could be undertaken of the stones discovered in the vicinity of bronze artefacts. Smaller and larger stones might have mitigated the power of bronze artefacts, which due to their uniqueness could have undermined the social order.

The very act of deposition in the ground of artefacts having an above-average value undoubtedly provided a clear message. The combination of that practice with the construction 
of a monumental structure strengthened the significance of such behaviour, as well as emphatically prolonging the impact of its content. This statement was addressed to members of the group, but the location of these activities in the marginal zone of the settlement indicates that its recipients were also 'strangers'. On the one hand, metals deposited in such a place could have been a gift for the supernatural forces (Hänsel 1997), or ancestors (see Giles 2007, 400-406), and on the other hand these actions may have been addressed to their neighbours, they were an act of marking of the border, they were also a manifestation of the potential and generosity of a given group. It should be noted that linguistic sources (Kowalski 1999) indicate a convergence in the perception of supernatural forces, the dead and representatives of other groups. The act of deposition fulfills its functions both when it was made in the presence of representatives of other neighbouring groups, as well as without their participation, as in social practice not all messages are addressed directly to the recipient. If a structure was built in a place where metal objects were deposited, a stone was placed or other traces of a rite remained visible (currently difficult to record by archaeological methods or unknown because of the randomness of such discoveries), such a place automatically became a non-verbal message, confirming the event and informing others of its importance. Reading such a message by members of other groups cultivating similar traditions was not a problem. In addition, this place both marked the end of the secure - appropriated world, as well as informing 'strangers' that they were entering a domain belonging to a particular community.

It is worth noting that traces of metallurgical activities are often discovered in the marginal parts of a settlement. At their borders were also deposited the post-production waste (Bradley 1998, XIX; Giles 2007, 400-406; Haaland 2004; Hingley 2006, 224-230; Mierzwiński 2003, 216; Woźny 2000, 143-145). In the context of the similarity which occurred between the symbolism of borders, borderlands and metal, an explanation of such arrangement of metallurgical production places by practical purposes alone (which usually is done) is undoubtedly a simplification.

The assemblages of metal objects fulfilled a range of functions which should be described as ordering the social world. They regulated the relationships in the group, establishing and consolidating social relations. They prevented significant social differentiation - by withdrawiing from cultural circulation objects which had gained too high a value and thereby giving an above-average prestige. Thus, they helped to avoid internal conflicts, which became more important with the increase in the number of these communities in the late Bronze Age and the early Iron Age. Rituals of deposition in the ground of metal products at all their stages integrated the group. The place where it was done formed a part of the cosmological patterns and thus the cultural norms, which allowed the community members to become familiarized with them and consolidate them in practice. Each cosmological pattern is visible at all levels of the world organization. The situation is similar when it comes to hoards which are symbolic gates to a certain inhabited zone. This system replicates the patterns perceptible at other levels of the organization (Fig. 1). The act of 


\begin{tabular}{|l|l|}
\hline & Cabin \\
\hline & Porder: \\
\hline
\end{tabular}

Fig. 1. Cosmological importance of places of passage in the picture of the world of the community of the late Bronze Age and the early Iron Age

metal products deposition at the border of an inhabited area also constituted a medium of intergroup communication, enabled the manifestation of wealth, prestige building, emphasizing the sovereignty and position equalization in the dialogue between communities partners with different potential. In this case, it created chances to control the conflicts. 
The increasing risk of conflict amongst the studied communities is indicated by several simultaneous processes. In the perspective of the presented study the most important was the increase in the frequency of hoards attributable to the $\mathrm{V}$ of Period the Bronze Age (HaB2-3) (Blajer 2001 75; Maciejewski 2016, 161-163, fig. 3.2.1). During this period, other phenomena also intensified: the development of 'defence' construction (Chochorowski 1993, 217-218; Harding 2000, 296; Niesiołowska-Wędzka 1974, 27-29, 173-196, fig. 1; Osgood et al. 2000, 141-144), the appearance (archaeologically perceptible in only a few places in Europe) of field systems (Harding 2000, 150-163; Yates 1999) and an increase in the frequency of bronze artefacts which could have served as weapons (see Blajer 2013, 93-94). All these phenomena should be associated with the growing importance of a sense of territoriality amongst these groups, which was caused by stress growing along with rapid demographic development of these communities, which is commonly recorded in archaeological sources (amongst others Kaczmarek 2002, 228-229; Lasak 2001, 425; Michalski 1983, 383; Mierzwiński 1994, 109-110; Ostoja-Zagórski 1982, 121; Przybyła and Blajer 2008, 76; Szamałek 2009, 65, 80; Wesolowski 1996, 31). The coincidence of the increase in the number of assemblages of metal objects deposited in the ground and water with the process of intensification of 'defence' construction at the same time was also noticed in other parts of Europe (Bradley 1998, 21, 139; Harding 2000, 355). The changes are significant and widespread, ipso facto giving rise to a new perspective concerning the phenomenon of the mass deposition of metal artefacts.

The formation of a new cultural system requires the community's openness to ideas, as well as people and products, there is also greater mobility of the community, and thus the borders become less important (see Kristiansen and Larsson 2005, 360-361; Mierzwiński $1992,128 ; 1994,102-103)$. However, with the solidification of cultural norms, territorial divisions and stresses which appeared in the course of increasing the size and number of groups, there appeared areas of conflicts which in reality of the described period took place between territorial or kin groups (Claessen 2006, 222-223; Helbling 2006, 116-120; Ostoja-Zagórski 1989, 177). Thus, the significance of both physical (borders), and symbolic divisions increased, which caused the need for a more clearly organized world. With this was associated behaviour, such as highlighting the importance of borders by depositing metal objects there. Of course, the scale of this phenomenon in terms of both the frequency of such assemblages as well as their inventory was related to the local availability of metal.

The quoted understanding, combining behaviour related to the physical space (a tendency towards the clear demarcation of borders along with population growth of described communities) with deposition in the ground of metal objects, also allows us to interpret the process of the decline of this cultural practice in the study area in a wider manner (along with the beginnings of the La Tène period). On the one hand, important cultural changes in Central Europe occurred during this period - the beginning of the La Tène world - which were associated with changes in deposition practices (Bradley 1998, 161172). On the other hand, the settlement of communities in question gradually changed, 
becoming less intense. These processes meant that the stress caused by population size decreased. Hence, one of factors determining the cultural behaviour of the analysed communities in the earlier period (hoard deposition) lost momentum, and as a result of both these processes the disappearance of the described custom occurred.

\section{CONCLUSION}

The research results and their interpretation presented clearly indicate that the data on the relationships between hoard deposition places with other elements of the cultural landscape (perceptible by archaeological methods) enrich our knowledge of both metal finds as well as the spatial perception of the analysed communities. The model tries to combine functions from various spheres of life of ancient societies and understand them in the context of a broad spectrum of humanistic knowledge. It indicates the need for similar research on finds from other zones, as well as use of the source base accumulated during the described research project for the consideration about the finds from the wet land as well as from settlements and burial grounds (taking into account the organization and spatial symbolism of these places). Equally important are excavations in places of hoard discoveries in Kaliszany and Stołężyn, which would help to verify this if the structures cited in their context were older barrows, or perhaps structures similar to the one discovered in Rosko.

Constant adaptation of new technologies to archaeological research means that it would be possible to extend the methods used in the presented project, thanks to the implementation of aerial photography with use of drones, laser scanning or prospecting with metal detectors and geophysical methods. It can be expected that it would allow the location of the remains of other structures analogous to the find from Rosko. Also, and which may seem controversial in the case of assemblages originally deposited in wet land, the implementation of such methods gives a strong research potential. Currently, many of these places are already drained and detailed prospection by means of modern methods would help to determine the context of such finds. Hypothetically it may be assumed that it would be possible to recognize structures similar to those discovered in Berlin-Spandau (Schwenzer 1997), or situations analogous to those known from Witaszkowo/Kozów (Kobyliński et al. 2015) or observations similar to those made during underwater research when the assemblages from Nętno and Trzynik were discovered (Rembisz 2009; 2011). In addition, the perspective should be expanded by taking into account the results of metallographic and microscopic examination, which would allow us to learn the individual characteristics of objects belonging to individual hoards. 


\section{References}

Anschuetz K. F., Wilshusen R. H. and Scheick C. L. 2001. An Archaeology of Landscapes: Perspectives and Directions. Journal of Archaeological Research 9(2), 157-211.

Arystoteles 2003. Dzieta wszystkie 2. Wstęp. Warszawa: PWN.

Ballmer A. 2010. Measuring the Mental - A Quantitative Approach to Mental Landscape Concepts in Prehistory. In. J. Müller (ed.), Landscapes and Human Development: The Contribution of European Archaeology. Proceedings of the International Workshop "Socio-Environmental Dynamics over the Last 12,00o Years: The Creation of Landscapes (1st-4th April 2009) (= Universitätsforschungen zur prähistorischen Archäologie 191). Bonn: Rudolf Habelt, 193-202.

Bartelheim M. 2009. Die Nutzung mineralischer ressourcen in der bronzezeit Mittel- und Südosteuropads. In. M. Bartelheim and H. Stäuble (eds.), Die Wirtschaftlichen grundlagen der bronzezeit Europas. The economic Foundations of the European Bronze Age. Rahden: Verlag Marie Leidorf, 177-188.

Bartnicka M. 1985. Wyobrażenia przestrzeni i ich badanie. Etnografia Polska 29(2), 23-37.

Blajer W. 2001. Skarby przedmiotów metalowych z epoki brązu i wczesnej epoki żelaza na ziemiach polskich. Kraków: Księgarnia Akademicka.

Blajer W. 2013. Młodsza epoka brąu na ziemiach polskich $w$ świetle badań nad skarbami. Kraków: Towarzystwo Wydawnicze „Historia Iagellonica”.

Bradley R. 1998. The Passage of Arms. An Archaeological Analysis of Prehistoric Hoard and Votive Deposits. Oxford-Oakville: Oxbow Books.

Brovender Y. M. 2009. Copper ores of The Northern Pontic Region as raw materials for production activity in the paleometal age (based on the study of The Kartamysh ore mining and matallurgy complex). In A. Kośko and V.I. Klochko (eds.), Routes between the seas: Baltic - BugBoh - Pont from the 3rd to the middle of the 1st millenium BC, (= Baltic-Pontic Studies 14). Poznań: Institute of Archaeology UAM, 103-123.

Brown R. 2006. Procesy grupowe. Dynamika wewnątrzgrupowa i międzygrupowa. Gdańsk: Gdańskie Wydawnictwo Pedagogiczne.

Buchowski M. 1987. Obrzędy przejścia. In Z. Staszczak (ed.), Stownik etnologiczny. Terminy ogólne. Warszawa-Poznań: PWN, 259-260.

Bujnicki T. 2006. O problemach kultury i literatury pogranicza. Kilka impresji badawczych. In $\mathrm{Me}$ chanizmy funkcjonowania pogranicza kulturowego. http://polonia.org.ua/2003-6/ konf/o9_2006/bujnitski.pdf

Bystroń J. S. 1939. Czynniki magiczno-religijne w osadnictwie. Przegląd Socjologiczny 7(1-2), 25-47.

Chochorowski J. 1993. Ekspansja kimmeryjska na tereny Europy Środkowej. Kraków: Wydawnictwo UJ.

Claessen H. J. M. 2006. War and State Formation: What is the Connection? In T. Otto, H. Thrane and H. Vandkilde (eds.), Warfare and Society. Archaeological and Social Anthropological Perspectives. Aarhus: Aarhus University Press, 217-226. 
Czarnowski S. 1956. Podział przestrzeni i jej rozgraniczenie w religii i magii. In N. Assorodobraj and S. Ossowski (eds.), Dzieta 3. Warszawa: PWN, 221-236.

Danka I. R. and Kowalski A. P. 200o. Kultura i wyobrażenia społeczeństw neolitycznych. Wybór słownictwa indoeuropejskiego. In H. van den Boom, A. P. Kowalski and M. Kwapiński (eds.), EIDOLON Kultura archaiczna $w$ zwierciadle wyobrażeń, słów i rzeczy. Gdańsk: Muzeum Archeologiczne w Gdańsku, 217-243.

Dąbrowski J. 1992. Uwagi o handlu brązem. In S. Czopek (ed.), Ziemie polskie we wczesnej epoce żelaza i ich powiązania z innymi terenami. Rzeszów: Muzeum Okręgowe w Rzeszowie, 91-99.

Dąbrowski J. 2012. Rola metalu w epoce brązu. In W. Blajer (ed.), Peregrinationes archaeologicae in Asia et Europa Joanni Chochorowski dedicatae. Kraków: Profil-Archeo and Instytut Archeologii UJ, 87-92.

DeMarrais E., Castillo L. J. and Earle T. 1996. Ideology, materialization and power strategies. Current Anthropology 37, 15-31.

Douglas M. 2007. Czystość i zmaza. Analiza pojęć nieczystości i tabu. Warszawa: PIW.

Eliade M. 1974. Sacrum, mit, historia. Warszawa: PIW.

Eliade M. 1993. Traktat o historii religii. Łódź: Opus.

Fogel J. 1983. Miedź i metale pochodne. In J. K. Kozłowski and S. K. Kozłowski (eds.), Człowiek i środowisko $w$ pradziejach. Warszawa: PWN, 141-152.

Fontijn D. R. 2002. Sacrificial Landscapes. Cultural Biographies of Persons, Objects and 'natural' Places in the Bronze Age of the Southern Netherlands, C. 230O-60o BC. Leiden: University of Leiden.

Gediga B. 1982. Metalurgia brązu w kulturze łużyckiej na Śląsku. Pamiętniki Muzeum Miedzi 1, 109-130.

Gedl M. 1982. Zarys dziejów metalurgii miedzi i brązu na ziemiach polskich do początków epoki żelaza. Pamiętniki Muzeum Miedzi 1, 33-66.

Giles M. 2007. Making metal an forging relations: ironworking in the British Iron Age. Oxford Journal of Archaeology 26, 395-413.

Golka M. 1999. Pogranicza - transgraniczność - transkulturowość. In L. Gołdka (ed.), Transgraniczność $w$ perspektywie socjologicznej - kontynuacje. Zielone Góra: Lubuskie Towarzystwo Naukowe, 13-26.

Haaland R. 2004. Technology, transformation and symbolism: ethnographic perspectives on European iron working. Norwegian Archaeological Review 37, 1-19.

Hall E. T. 1978. Ukryty wymiar. Warszawa: PIW.

Hall E. T. 1984. Poza kulturq. Warszawa: PWN.

Hall E. T. 1987. Bezgłośny język. Warszawa: PIW.

Hänsel B. 1997. Gaben an die Götter. Schätze der Bronzezeit Europas eine Einführung. In A. and B. Hänsel (eds.), Gaben an die Götter. Schätze der Bronzezeit Europas. Berlin: Staatliche Museen zu Berlin, 11-22.

Harding A. F. 2000. European societies in the Bronze Age. Cambridge: Cambridge University Press.

Helbling J. 2006. War and Peace in Societies without Central Power: Theories and Perspectives. In T. Otto, H. Thrane and H. Vandkilde (eds.), Warfare and Society. Archaeological and Social Anthropological Perspectives. Aarhus: Aarhus University Press, 113-139. 
Hingley R. 2006. The Deposition of iron objects in Britain during the late prehistoric and Roman Periods: contextual analysis and the significance of iron. Britannia 37, 213-257.

Hołubowicz W. 1960. Okres patriarchalnej wspólnoty pierwotnej epoki brązu i wczesnych okresów epoki żelaza. In K. Maleczyński (ed.), Historia Śląska 1 do roku 1763. 1 do połowy XIV w. Wrocław: Ossolineum, 34-144.

Jałowiecki B. and Szczepański M. S. 2006. Miasto i przestrzeń w perspektywie socjologicznej. Warszawa: Wydawnictwo Naukowe Scholar.

Jaskanis D. (ed.) 1996. Archeologiczne Zdjęcie Polski - metoda i doświadczenia. Próba oceny (= Biblioteka Muzealnictwa i Ochrony Zabytków. Seria B. 95). Warszawa: Ministerstwo Kultury i Sztuki Generalny Konserwator Zabytków.

Kaczmarek M. 2002. Zachodniowielkopolskie społeczności kultury tużyckiej w epoce brąu. Poznań: Wydawnictwo Naukowe UAM.

Kantner J. 2008. The archaeology of regions: from discrete analytical toolkit to ubiquitous spatial perspective. Journal of Archaeological Research 16, 37-81.

Kobyliński Z., Kobylińska U., Nebelsick L. D. and Wach D. 2015. Święte źródło w Kozowie: kontekst archeologiczny „skarbu z Vettersfelde”. In A. Jaszewskiej and A. Michalaka (eds.) Woda - żywiot ujarzmiony i nieujarzmiony. VII Polsko-Niemieckie Spotkania Archeologiczne Janowiec, 24-25 maja 2012 (= Biblioteka Archeologii Środkowego Nadodrza 8). Zielona Góra: SNAP Oddział Lubuski, 111-121.

Kondracki J. 2009. Geografia regionalna Polski. Warszawa: PWN.

Kośko A. and Kločko V. I. 2011. Szlaki tranzytowe bałtycko-pontyjskiego międzymorza, wczesne etapy rozwoju: IV/III-połowa I tyś. przed Chr. Zarys projektu badawczego. In M. Ignaczak, A. Kośko and M. Szmyt (eds.), Między Battykiem a Morzem Czarnym. Szlaki międzymorza IV-I tys. przed Chr. (= Archaeologia Bimaris. Dyskusje 4). Poznań: Wydawnictwo Poznańskie, 11-18.

Kowalski A. P. 1999. Dar, import, obcość. Szkic z prahistorycznej etnologii kontaktu kulturowego. In S. Kukawka (ed.), Szkice prehistoryczne. Źródła - metody - interpretacje, Toruń: Wydawnictwo Naukowe UMK, 13-32.

Kowalski A. P. 2006. Sługa ognia w kuźni i na pogrzebowym stosie. O roli metalurgów w epoce ciałopalenia. In A. Z. Bokiniec and J. Sobieraj (eds.), Pruthenia Antiqua. Studia do pradziejów i wczesnej historii ziem pruskich 2. Na przełomie epok na rubieży światów. Olsztyn: SNAP oddział w Olsztynie, 19-24.

Krajewski P. 2007. Struktury osadnicze późnej epoki brązu-wczesnej epoki żelaza na Pomorzu Zachodnim. Wybrane zagadnienia. In M. Fudziński and H. Paner (eds.), Aktualne problemy kultury tużyckiej na Pomorzu. Gdańsk: Muzeum Archeologiczne w Gdańsku, 35-46

Kristiansen K. and Larsson T. B. 2005. The Rise of Bronze Age Society. Travels, Transmissions and Transformations. Cambridge: Cambridge University Press.

Lasak I. 2001. Epoka brąu na pograniczu śląsko-wielkopolskim II. Zagadnienia kulturowo osadnicze. Wrocław: Sudety.

Leach E. 1989. Kultura i komunikowanie. Logika powiązań symbolicznych. Wprowadzenie do analizy strukturalnej w antropologii społecznej. In E. Leach and A. J. Greimas (eds.), Rytuat i narracja. Warszawa: PWN, 21-98. 
Leeuw van der G. 1978. Fenomenologia religii. Warszawa: Książka i Wiedza.

Lejman J. 1999. Człowiek jako „zwierze terytorialne”. In S. Symotiuk and G. Nowak (eds.), Przestrzeń w nauce wspótczesnej 2. Lublin: Wydawnictwo UMCS, 81-107.

Lévi-Strauss C. 1969. Myśl nieoswojona. Warszawa: PWN.

Levy J. E. 1982. Social and Religious Organization in Bronze Age Denmark. An Analysis of Ritual Hoard Finds (= British Archaeological Reports. International Series 124). Oxford: Archaeopress.

Machajewski H. and Maciejewski M. 2006. Skarb ludności kultury łużyckiej z Roska nad Notecią. In H. Machajewski and J. Rola (eds.), Pradolina Noteci na tle pradziejowych i wczesnośredniowiecznych szlaków handlowych. Poznań: SNAP oddział w Poznaniu, 127-146.

Machnik J. 1982. Uwagi o wyrobach metalowych z początków epoki brązu w południowo-wschodniej Polsce. Pamiętniki Muzeum Miedzi 1, 79-100.

Maciejewski M. 2006. Rosko, stan. 4, gm. Wieleń. Z badań nad osadnictwem kultury łużyckiej. In H. Machajewski and J. Rola (eds.), Pradolina Noteci na tle pradziejowych i wczesnośredniowiecznych szlaków handlowych. Poznań: SNAP oddział w Poznaniu, 201-216.

Maciejewski M. 2015. The perspective of physical space in a study of hoards from the late Bronze Age and the early Iron Age. Sprawozdania Archeologiczne 67, 67-76.

Maciejewski M. 2016. Metal - granica - rytuat. Badania nad depozytami przedmiotów metalowych $w$ kontekście sieci osadniczej (= Archaeologia Bimaris. Monografie 7). Poznań: Wydawnictwo Nauka i Innowacje.

Makarowicz P. 2010. Trzciniecki krąg kulturowy - wspólnota pogranicza Wschodu i Zachodu Europy (= Archaeologia Bimaris. Monografie 3). Poznań: Wydawnictwo Poznańskie.

Mamzer H. 2004. Archeologia i dyskurs: rozważania metaarcheologiczne. Poznań: IAE PAN.

Mazurowski R. 1980. Metodyka archeologicznych badań powierzchniowych (= Metodologia Nauk 19). Warszawa-Poznań: PWN.

Michalski J. 1983. Typy osad otwartych kultury łużyckiej, ich rozprzestrzenienie na terenie Polski oraz liczba zamieszkującej je ludności. In W. Hensel (ed.), Przemiany ludnościowe i kulturowe I tysiąclecia p.n.e. na ziemiach między Odra a Dnieprem. Wrocław: Ossolineum, 375-389.

Mierzwiński A. 1992. W kwestii przemian osadniczych na przełomie epoki brązu i wczesnej epoki żelaza (z uwzględnieniem specyfiki śląskiej). In S. Czopek (ed.), Ziemie polskie we wczesnej epoce żelaza i ich powiązania z innymi terenami. Rzeszów: Wydawnictwo Muzeum Okręgowego, 127-132.

Mierzwiński A. 1994. Przemiany osadnicze społeczności kultury tużyckiej na Śląsku. Wrocław: IAE PAN.

Mierzwiński A. 2003. Znaki utrwalone w glinie. Społeczno-obrzędowe aspekty działań wytwórczych końca epoki brqzu i wczesnej epoki żelaza. Model nadodrzański. Wrocław: IAE PAN.

Mierzwiński A. 2012a. Tajemnice pól popielnicowych. Pogranicze doczesności i zaświatów w perspektywie pradziejowej antropologii śmierci. Wrocław: IAE PAN.

Mierzwiński A. 2012b. Achilles hiperborejski - esej o mitycznym spełnieniu. In W. Blajer (ed.), Peregrinationes archaeologicae in Asia et Europa Joanni Chochorowski dedicatae. Kraków: Profil-Archeo and Instytut Archeologii UJ, 549-555. 
Neustupný E. 1998 Structures and events: The theoretical basis of spatial archaeology. In E. Neustupný E. (ed.), Space in prehistoric Bohemia. Praha: Institute of Archaeology, Academy of Sciences of the Czech Republic, 9-44.

Niesiołowska-Wędzka A. 1974. Początki i rozwój grodów kultury tużyckiej. Wrocław: Ossolineum.

Nowica E. 1998. Świat czlowieka - świat kultury. Systematyczny wykład problemów antropologii kulturowej. Warszawa: PWN.

Ogryzko-Wiewórkowski H. 2003. Od proksemiki do socjometrii. In G. Nowak and S. Symotiuk (eds.), Przestrzeń we współczesnej nauce. Zamość: Wyższa Szkoła Zarządzania i Administracji, 171-178.

Osgood R., Monks S. and Toms J. 2000. Bronze Age Warfare. Stroud: Sutton Publishing.

Ostoja-Zagórski J. 1982 Przemiany osadnicze, demograficzne i gospodarcze w okresie halsztackim na Pomorzu. Wrocław: Ossolineum.

Ostoja-Zagórski J. 1989. Mikrostruktury społeczne epoki brązu w Europie Środkowej. Próba rekonstrukcji. Przeglad Archeologiczny 36, 169-208.

Pare C. F. E. 2000. Bronze and the Bronze Age. In C. F. E. Pare (ed.), Metals make the world go round. The supply and circulation of metals in Bronze Age Europe. Oxford-Oakville: Oxbow Books, 1-38.

Pellegriono P. 1989. Rozwój przestrzenny, tożsamość kulturowa, stosunek do innych i przemiany terytorium regionalnego; prezentacja metody badań. In J. Wódz (ed.), Przestrzeń znacząca. Studia socjologiczne. Katowice: Śląski Instytut Naukowy, 61-76.

Popko M. 1980. Mitologia hetyckiej Anatolii. Warszawa: Wydawnictwa Artystyczne i Filmowe.

Posern-Zieliński A. 200o. Rzeka jako element tożsamości kulturowej. Rzeki 9, 11-40.

Przybyła M. S. and Blajer W. 2008. Struktury osadnicze w epoce brazu i wczesnej epoce żelaza na obszarze podkarpackiej wysoczyzny lessowej między Wistokiem i Sanem. Kraków: Wydawnictwo UJ.

Rączkowski W. 2011. Kwestia identyfikacji przeszłych szlaków tranzytowych metodami teledetekcyjnymi. In M. Ignaczak, A. Kośko and M. Szmyt (eds.), Między Battykiem a Morzem Czarnym. Szlaki międzymorza IV-I tys. przed Chr. (= Archaeologia Bimaris. Dyskusje 4). Poznań: Wydawnictwo Poznańskie, 61-69.

Rembisz A. 2009. Znaleziska naczyń, ozdób, broni i narzędzi z Jeziora Gągnowskiego w Nętnie, gm. Drawsko Pomorskie (stanowisko 38). In J. Gackowski (ed.), Archeologia epok brązu i żelaza. Studia i materiaty 1, Torun: Wydawnictwo Naukowe UMK, 93-121.

Rembisz A. 2011. Dar wotywny złożony z ozdób, narzędzi i broni odkryty w Jeziorze Kamienica, w miejscowości Trzynik, pow. Kołobrzeg (stanowisko 12). Acta Universitatis Nicolai Copernici, Archeologia 21. Archeologia podwodna 6, 11-24.

Sahlins M. D. 2006 Wyspy historii. Kraków: Wydawnictwo UJ.

Schwenzer S. 1997. „Wanderer kommst Du nach Spa...”. Der Opferplatz von Berlin-Spandau. Ein Heiligtum für Krieger, Händler und Reisende. In A and B Hänsel (eds.), Gaben an die Götter. Schätze der Bronzezeit Europas. Berlin: Staatliche Museen zu Berlin, 61-66.

Stevens F. 2008. Elemental Interplay: the Production, Circulation and Deposition of Bronze Age Metalwork in Britain and Ireland. World Archaeology 40(2), 238-252. 
Spros J. 1994. Starożytność i początkowy okres wczesnego średniowiecza. In J. Lindmajer (ed.), Dzieje Stawna. Słupsk: Urząd Miejski w Sławnie, Wyższa Szkoła Pedagogiczna w Słupsku, 15-39.

Suchowska P. 2010. Kontakty społeczności Europy środkowej i strefy egejskiej w drugim tysiącleciu przed Chr. Próba analizy archeologiczno-chronometrycznej. Poznań (unpublished PhD Thesis in AMU Library).

Szamałek K. 2009. Procesy integracji kulturowej w mtodszej epoce brązu i początkach epoki żelaza na Pojezierzu Wielkopolskim. Poznań: IAE PAN.

Tilley Ch. 1994. A Phenomenology of Landscape. Places, Paths and Monuments. Oxford-Providence: Berg.

Tuan Y.F. 1987. Przestrzeń i miejsce. Warszawa: PIW.

Wallis A. 1990. Socjologia przestrzeni. Warszawa: Niezależna Oficyna Wydawnicza NOWA.

Wesołowski S. 1996. Próba oceny stanu badań nad osadnictwem kultury łużyckiej na Pomorzu Zachodnim. In M. Dworaczyk, P. Krajewski and E. Wilgocki (eds.), 50 lat archeologii polskiej na Pomorzu Zachodnim. Szczecin: SNAP odział Szczecin, 27-48.

Wojciechowski K. H. 1998. Koncepcja przestrzeni geografii humanistycznej. In S. Symotiuk and G. Nowak (eds.), Przestrzeń w nauce wspótczesnej 1. Lublin: Wydawnictwo UMCS, 141-154.

Woźny J. 1999. Wstęp do hermeneutyki przestrzeni. In S. Kukawka (ed.), Szkice prehistoryczne. Źródta - metody - interpretacje. Toruń: Wydawnictwo Naukowe UMK, 43-64.

Woźny J. 2000. Symbolika przestrzeni miejsc grzebalnych $w$ czasach ciałopalenia zwłok na ziemiach polskich. Bydgoszcz: Wydawnictwo Uczelniane WSP w Bydgoszczy.

Wódz K. 1989. Przestrzeń w teorii i badaniach psychologicznych. In J. Wódz (ed.), Przestrzeń znacząca. Studia socjologiczne. Katowice: Śląski Instytut Naukowy, 249-262.

Yates T. D. 1999. Bronze Age Field Systems in the Thames Valley. World Archaeology 18(2), 157-170.

Załęska M. 2007. Lingwistyka w badaniach kultury: analiza językowa konceptualizacji pojęcia „wróg”. In J. Axer and J. Olko (eds.), Wyobrażenia wroga $w$ dawnych kulturach, Warszawa: Wydawnictwo DiG, 27-39.

Zapłata R. 2005. Archeologiczne studia nad przestrzeniq. Zastosowanie systemów informacji geograficznej $w$ badaniach nad wczesnośredniowiecznym osadnictwem grodowym na Pomo$r z u$. Poznań (unpublished PhD thesis in AMU Library).

Znaniecki F. 1999. Socjologiczne podstawy ekologii ludzkiej. In M. Malikowski and S. Solecki (eds.), Spoleczeństwo i przestrzeń zurbanizowana. Teksty źródłowe. Rzeszów: Wydawnictwo Uniwersytetu Rzeszowskiego, 122-146. 